\title{
Customer Satisfaction in Seagreen Stevedoring and Logistics Pvt. Limited
}

\author{
Premalatha.K, Gowtham Aashirvad, A.Kamal
}

\begin{abstract}
The thought is that one should look to make such a degree of consumer loyalty, so they don't see important to think about the contenders' offers. Numerous business sectors are portrayed by wantonness, with reference to the client base. In these business sectors, clients will purchase a brand for a chance and after that it is probably going to purchase another next time. Associations ought to endeavor honestly to create social promoting techniques to keep up and fortify client reliability. In this manner, this investigation is centered around consumer loyalty with extraordinary reference to Seagreen Steveodoring and Logistics (India) Pvt. Restricted.
\end{abstract}

\section{Keywords : Seagreen Steveodoring Logistics}

\section{INTRODUCTION}

Today we are witnessing the increasing importance of consumer services and their satisfaction, which become a competitive weapon of the organization. The factors behind this growth are: the continuous changes in the customer expectations, the consumer demands more, he is more sophisticated than he was 30 years ago. The eduction in the power of the brand growth by the technologies of the competitive products, thus making difficult to perceive the differences between products. The specialized literature identified three components of customer service: re-transactional elements that create a favorable climate for customer service: the customer service policies and programs, the organizational structure necessary to implement the customer service policy, the flexibility of the system or its ability to respond to customer needs. Transactional elements established by meeting the logistic function: the availability of the product in the stock, information about the order, the order cycle duration. Post-transactional elements of customer service are generally those that support the product in use: product guarantee, maintenance service, product replacement, client complaint resolution, and product reimbursement. It is very difficult for any company to identify its customers' needs. However, it often happens that customer's fall into groups or "segments" similar in terms of level of serving. The logistics specialist should know exactly what the service issues which differentiate customers are. Customer service is perceptual and not always reflects what the client wants most. For

Revised Manuscript Received on July 22, 2019.

K.Premalatha ,Department of MBA,Bharath institute of Higher Education \& Research,Tamilnadu,India, Email: premalathak@gmail.com

Mr. Gowtham Aashirvad, Assistant Professor, Department of MBA,Bharath institute of Higher Education \& Research,Tamilnadu,India Email:kgowthamaashirwad123@gmail.com

Dr.A.Kamal, Associate Professor ,Department of EEE,Bharath institute of Higher Education \& Research,Tamilnadu, India, Email ak2_anvi@yahoo.co.in example, "stock availability" is a widespread internal measure of business performance, and "on time delivery" is an external measure valued by customers. It is therefore important that companies establish a set of service criteria which are significant for customers.

Although logistics has been performed since the beginning of civilization, implementing 21 st century best practices is one of the most exciting and challenging operational areas of supply chain management. Logistics involves the management of order processing, inventory, transportation, and the combination of warehousing, material handling, and packaging, all integrated throughout a network of facilities. The goal of logistics is to support procurement, manufacturing, and customer accommodation operational requirements. Within a firm the challenge is to coordinate functional competency into an integrated operation focused on servicing customers. [14], [ 16], [18]

Many organizations are adapting difficultly to the competitive environment because in the past they have focused on the traditional aspects of marketing development of production, promotional activities and price competition issues focused more on getting customers than on keeping them. The dimensions of a transactional marketing strategy, which is not sufficient at present. [1],[ 3],[5]

\section{RESEARCH METHODOLOGY}

Research is a craft of logical examination. It alludes to a systematized exertion to pick up of new learning. Philosophy incorporates an accumulation of hypotheses, ideas or thoughts as they identify with a specific field of request. It alludes to in excess of a straightforward arrangement of strategies. [14],[ 16], [18]

The research methodology aspect has special importance as it helps in empirical investigation. The methodology adopted to study customer satisfaction in seagreen stevedoring and logistic pvt. Ltd. questionnaire method [2 ],[4],[6].

\section{A. Scope of the study:}

- It improves the performances of the company.

- It helps to promote business.

- It helps to build relationship with customers

- It helps to fulfil the customer's expectation.

- This study provides the impact of the level of logistics service in the market.

- This project determines the trade and logistics management facility. 


\section{OBJECTIVES OF THE STUDY}

Primary objective:

To identify customer satisfaction in seagreen stevedoring and logistics private ltd.

\section{Secondary objectives:}

1. To understand customer satisfaction.

2. To study the relationship between the customer and transporter.

3. To identify the customer'sproblems.

4. To find out feasible suggestion to the company about the improvement in quality of services

5. To find out customer opinion towards time and price factors of the company.

\section{RESEARCH DESIGN}

Research design can be thought of as the structure of research. It is the glue that holds all the elements in a research project together. Research design is a vital part of the research study. It is the logical \& systematic planning and directing of piece of research. It is the master plan and blue print of the entire study. Researcher has used descriptivedesign in the study.

\section{A. Descriptive research:}

Descriptive research design is the research design followed in this project, which are concerned with describing the characteristics of a particular individual, or of a group. This study concerned with the specific predictions, which narration of facts and characteristics concerning individual and group. In descriptive research, the researcher must be able to define clearly, what he wants to measure and must find adequate methods for measuring it along with clear cut definition of the 'population' of the study. Since the aim is to obtain complete and accurate information in the studies, the procedure to be used must be carefully planned.

\section{B. Method of Data collection:}

The nature of data sources is the primary data as well as secondary data.

$>$ Primary data: The primary data collection includes the views of employees of HR department and the various applicants available and students pursuing training which was collected through separate questionnaires. The applicants were personally interviewed to get the required information. The questionnaires were distributed to the applicants from various departments like personnel, sales \&distribution, production, accounts, HR, marketing, mechanical etc. Each questionnaire was structured one containing questions which are of multiple choice type having a like the five point scaling method. Each of the applicants was interviewed personally during the survey. [7],[ 9], [11]

\section{Method used for collecting primary data:}

- Questionnaire

$>$ Secondary data: The secondary data was collected from the organization's files, journals, records, annual reports, website of the company etc. Data collected related to history of training and development at IMFA and its vision, mission, strategic goals are collected from official documents, periodicals literature and broachers available in various departments of the organization. [8],[10],[12]
D. Methods used for collecting secondary data:

- Internet

$$
X^{2}=\sum \frac{(o-e)^{2}}{e}
$$

Percentage analysis:

Percentage Analysis is applied to create a contingency table from the frequency distribution and represent the collected data for better understanding.Percentage Analysis is applied to create a contingency table from the frequency distribution and represent the collected data for better understanding

Correlation analysis:

Correlation coefficient analysis is used to measure the strength of the linear relationship between two attributes of debt market investments.

\section{E. Limitations of the study:-}

Detail study is not possible due to lake of time.Some of the employees would not reveal much information due to fear of their superiors. The sample size was small due to time constraint which might not be true representative of entire population.Some of the respondents have not responded totally.Biases might have crept up on the part of the management while giving answers. [13], [15], [ 17]

\section{TABLE NO 1:CUSTOMERS USING SEAGREEN}

\section{SERVICES}

\begin{tabular}{|l|l|l|l|}
\hline SL.NO & DURATION & RESPONDENTS & PERCENTAGE \\
\hline 1 & $0-5$ months & 0 & 0 \\
\hline 2 & $6-11$ months & 13 & 10.4 \\
\hline 3 & $1-2$ years & 28 & 22.4 \\
\hline 4 & $2-3$ years & 46 & 36.8 \\
\hline 5 & 3 or more & 38 & 30.4 \\
\hline
\end{tabular}

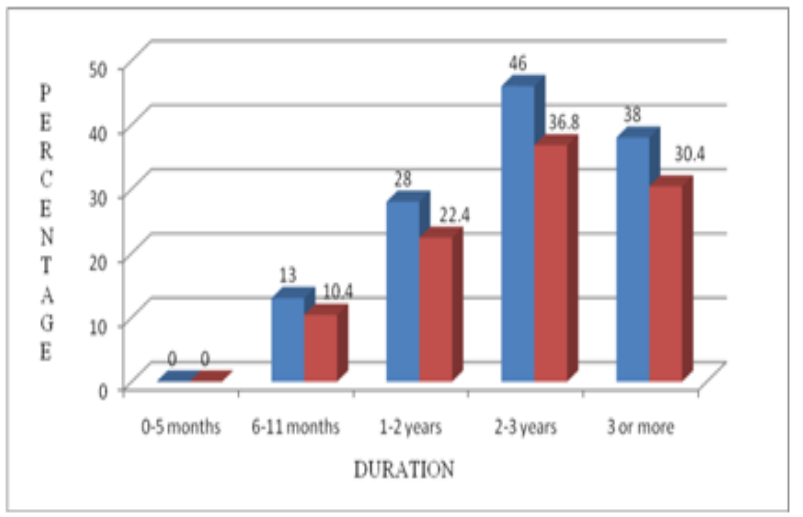

I 
CHART NO 1 CUSTOMER USING SEAGREEN SERVICES

Table 2: Prioritising seagreen Services

\begin{tabular}{|l|l|l|l|}
\hline SL.NO & PRIORITY & RESPODENTS & PERCENTAGE \\
\hline 1 & COST & 28 & 22.4 \\
\hline 2 & & & \\
\hline 3 & TIME & 19 & 15.2 \\
\hline 4 & QUALITY & 48 & 38.4 \\
\hline
\end{tabular}

CHARTNO 4.5 : PRIORITISING SEAGREEN STEVEDORING PRIVATE LTD.

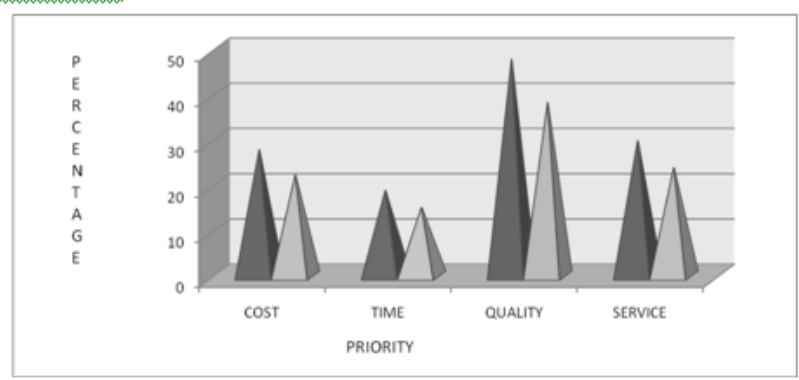

Fig 2: Prioritising seagreen Services

INFERENCE: From the above table about $48 \%$ customer prioritise seagreen Logistics because of quality and about $30 \%$ people prefer because of its service whereas people least prefer seagreen logistics with respect to time. [20],[ 22], [24]

Table 3:frequency of transporting goods

\begin{tabular}{|l|l|l|l|}
\hline SL.NO & FREQUENT & RESPODENTS & PERCENTAGE \\
\hline 1 & Everyddy & 25 & 20 \\
\hline 2 & $2 .-3$ deys & 33 & 26.4 \\
\hline 3 & Weasly & 26 & 20.8 \\
\hline 4 & Fortright & 27 & 21.6 \\
\hline 5 & Nonthly & 14 & 11.2 \\
\hline
\end{tabular}

CHART NO 4.7: FREQUENCY OF TRANSPORTING GOODS

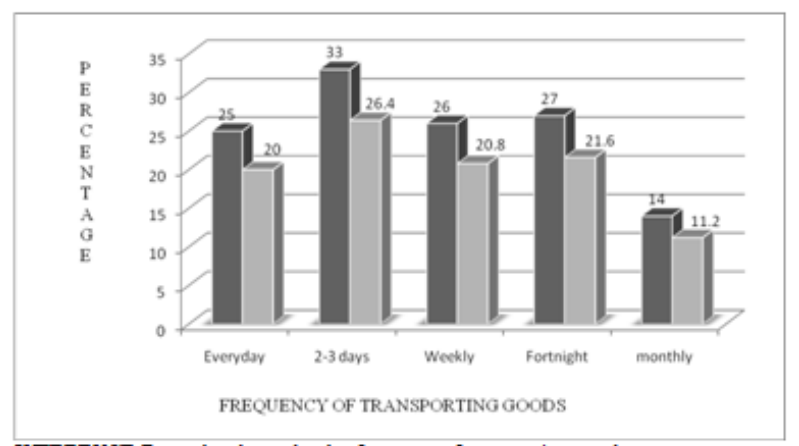

IDFFRENCF.From the above datathe frequency of transporting goods vary.

Table 4:satisfaction level towards seagreen

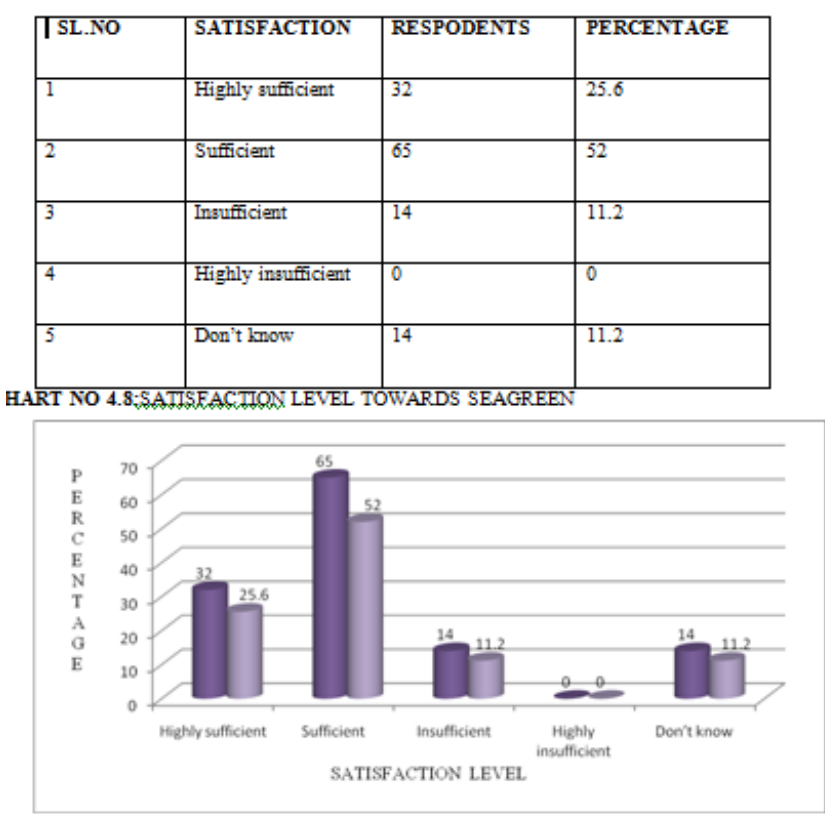

Table 5:Delivery schedule of vehicle
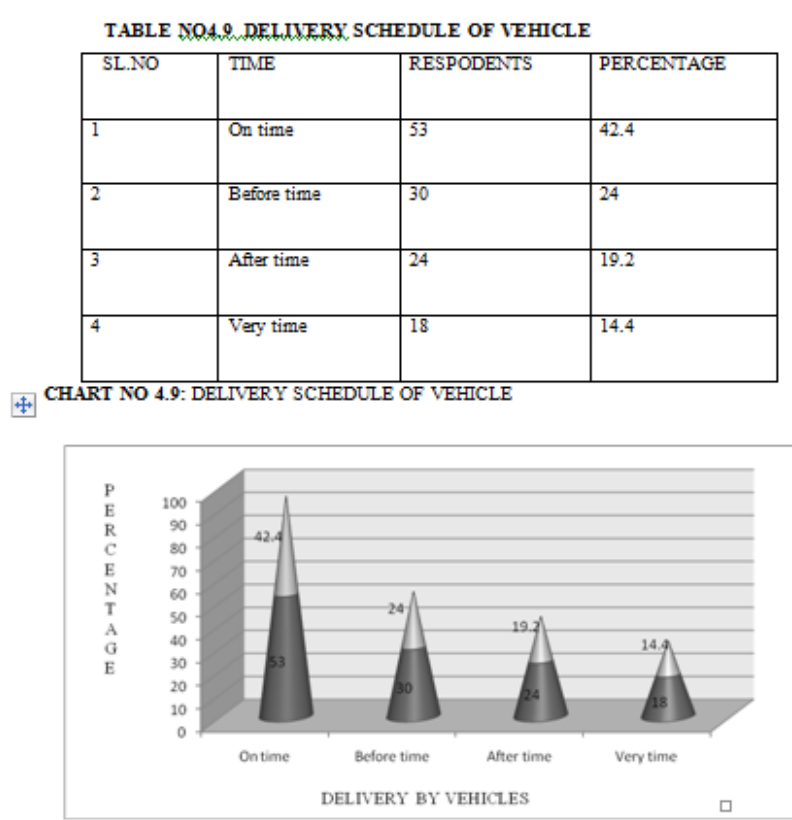

INFERENCE: It's good to see from the data collected that about $42.4 \%$ delivery by vehicles reaches on time but it's even bad to sea that some of the vehicles reaches after time according to people i. $19.2 \%$ 
Table 6:CHI SQUARE analysis

4.1 CHI-SQUARE ANALYSIS

\begin{tabular}{|l|l|l|l|l|l|}
\hline & $\begin{array}{l}\text { HIGHY } \\
\text { SUFFICIENT }\end{array}$ & SUFFICIENT & INSUFFICIENT & $\begin{array}{l}\text { DON'T } \\
\text { KNOW }\end{array}$ & TOTAL \\
\hline $\begin{array}{l}\text { SELF } \\
\text { EMIPLOYED }\end{array}$ & 10 & 15 & 10 & 5 & 40 \\
\hline PROFESSIONALS & 20 & 44 & 2 & 7 & 73 \\
\hline OTHERS & 2 & 6 & 2 & 2 & 12 \\
\hline TOTAL & 32 & 65 & 14 & 14 & 125 \\
\hline
\end{tabular}

USNG THE ABOVE VALUE AND PUTTING IT IN FORMULA WE GET

$$
X^{2}=\sum \frac{(o-e)^{2}}{e}
$$

$\mathrm{E}=(\mathrm{R} . \mathrm{T} *$ C.T $/ \mathrm{G} . \mathrm{T}$

TABLE ANAL YSIS

\begin{tabular}{|l|l|l|l|l|}
\hline $\mathbf{O}$ & $\mathbf{E}$ & $(\mathbf{O}-\mathbf{E})$ & $(\mathbf{O}-\mathrm{E})^{\star}(\mathbf{O}-\mathrm{E})$ & $\begin{array}{l}\left((\mathbf{O}-\mathbf{E})^{\star}(\mathbf{O}-\right. \\
\mathbf{E})) \mathbf{E}\end{array}$ \\
\hline 10 & 10.24 & -0.24 & 0.058 & 0.005 \\
\hline 15 & 20.8 & -5.8 & 33.64 & 1.617 \\
\hline 10 & 4.48 & 5.52 & 30.470 & 6.801 \\
\hline 5 & 4.48 & 0.52 & 0.270 & 0.060 \\
\hline 20 & 18.69 & 1.31 & 1.716 & 0.0918 \\
\hline 44 & 37.96 & 6.04 & 36.481 & 0.961 \\
\hline 2 & 8.176 & -6.176 & 38.142 & 4.665 \\
\hline 7 & 8.176 & -1.176 & 1.382 & 0.169 \\
\hline 2 & 3.072 & -1.072 & 1.149 & 0.374 \\
\hline 6 & 6.24 & -0.24 & 0.0576 & 0.009 \\
\hline 2 & 1.344 & 0.656 & 0.430 & 0.320 \\
\hline 2 & 1.344 & 0.656 & 0.430 & 0.320 \\
\hline
\end{tabular}

\begin{tabular}{|l|l|l|l|l|}
\hline TOTAL & & & & 15.392 \\
\hline
\end{tabular}

\section{DEGREE OF FREEDOM $=(\mathrm{r}-1)(\mathrm{c}-1)$ \\ $=(3-1(4-1)=6$ \\ Table xalue -12.502. \\ Calculated value: 15.392}

As table value is smaller than calculated value altemative hypothesis is accepted. hence, it is significant and customers are satisfied with the seagreen logistics

\section{RESULTS}

It is seen that about $50 \%$ of people are at the age $26-35$ and least are from the age under 25 .whereas $30 \%$ of people from $45 \&$ above and about $35 \%$ of people are from the 36-45.Majority of customers are male i.e about $80 \%$ and females are 40\%.[25],[27],[29]

About $73 \%$ of people are professional $40 \%$ of people are professional and $12 \%$ are others $.40 \%$ Of people came to know about seagreen through newspaper and $34.4 \%$ came to know through word of mouth and $20 \%$ of people came to know through magazine.

About $48 \%$ customer prioritise seagreen Logistics because of quality and about $30 \%$ people prefer because of its service whereas people least prefer seagreen logistics with respect to time.

the frequency of transporting goods vary. About 20\% people transport everyday. and highest frequency is $26.4 \%$ of transporting goods i.e for $2-3$ days and the lowest is $11.2 \%$ for transporting goods monthly.

it's good to see that more than $50 \%$ are satisfied with the seegreen and about $25.6 \%$ are highly sufficient with seagreen . but $11.2 \%$ people are not satisfied nor they know the satisfaction level towards seagreen.
It's good to see from the data collected that about $42.4 \%$ delivery by vehicles reaches on time but it's even bad to see that some of the vehicles reaches after time according to people i.e $19.2 \%$

about $40 \%$ of people rates seagreen average in terms of staffing and about $36 \%$ of people rates seagreen good and $24 \%$ excellent in terms of staffing

it is observed that $37.6 \%$ of people rated good to seagreen logistics in terms of packaging whereas $32 \%$ of people rated average and about $28 \%$ of people rated excellent. But $2.4 \%$ of people rated poor towards seagreen on the basis of packaging from the study it is observed that about $52 \%$ of people are satisfied which is good. And about 36\% of people have neutral feelings towards seagreen in terms of facilities and services and lowest rating is for strongly satisfied which is about $4.8 \%$ of people.

it is observe that about $63.2 \%$ of people agree that they are satisfied with the vehicle condition provided by seagreen and about $36.8 \%$ of people are agree with it.

From the study it can be seen that about $36 \%$ of people rates seagreen average in terms of Handling goods and about $40 \%$ of people rates seagreen good and $24 \%$ excellent in terms of handling goods.

it is observed that about 52\% of people are satisfied which is good. And about $36 \%$ of people have neutral feelings towards seagreen in terms of Information provided incase of vehicle breakdown and lowest rating is for strongly satisfied which is about $4.8 \%$ of people.

tis observed that about $41.6 \%$ of people says that the distance of branches, awrehouses, booking points and delivery spots are closeby. And about $39.2 \%$ of people says that it is near and about $19.2 \%$ of people says they are far.

From the study about $32 \%$ of people are satisfied with the tracking system adopted by seagreen bit it's sad to see people about $2.4 \%$ are highly dissatisfied. And about $27.2 \%$ of people are highly satisfied and 1 bout $17.6 \%$ people are dissatisfied with the tracking system adopted

About $68 \%$ people agree that seagreen needs more container terminals and about $24 \%$ people strongly agree and about $8 \%$ people feel neutral about it

\section{DISCUSSIONS}

As more customer felt that the company have to improve their import handling.

As most of customers are connected through mail. All business deals can be in mail form so, that tracking system can be updated regularly.

As most of customers want to deal with seagreen they want seagreen to add up more container terminals

As customers not much satisfied with packaging. So, it is needed to do it properly.

As the activities are getting delayed in customs parts, proper relationship to be maintained with customs clearance office to quicken the process.

Vehicle breakdown details should be updated regularly for all shipment as still some people are not satisfied with the operation. 


\section{CONCLUSIONS}

As the majority of the clients are happy with the administrations given by the association, The organization needs to hold the clients by giving more client care by making restorative move in the entirety of their impediments like traditions process, import taking care of and worth included administrations. The clients can utilize this implies all around effectively. Simultaneously, client administration assumes a significant job in pulling in new clients. Another accentuation in advertising and coordinations is increasingly across the board - making client connections. The thought is that one should try to make such a degree of consumer loyalty, so they don't see important to think about the contenders' offers. Numerous business sectors are portrayed by indiscrimination, with reference to the client base. In these business sectors, clients will purchase a brand for a chance and after that it is probably going to purchase another next time. Associations ought to endeavor scrupulously to create social advertising procedures to keep up and reinforce client loyaltUsing this undertaking our looking through procedure turns out to be simple. The organization has accomplished more benefit. This organization has successfully supplanted numerous other vehicle company. Hence mass activity in theseagreen stevedoring and logisticPvt. Ltd. is less expensive and is probably the most ideal approaches to move the crude products and unpackaged material inside the nation or abroad.

\section{REFERENCES}

1) BharthVajan R., Ramachandran S.,Psychographic dimensions of training,2016,International Journal of Pharmacy and Technology,V-8,I-4,P-23727-23729

2) Balakrishnan P., Bharthvajan R.,A study on human resource planning in hospitals in Chennai City,2014,International Journal of Applied Engineering Research,V-9,I-22,P-7503-7507

3) Priyadarsini P., Bharthvajan R.,Role of emotional intelligence training programme in reducing the stress of the nurses,2014,International Journal of Applied Engineering Research,V-9,I-22,P-7411-7421

4) Kerinab Beenu G., Bharthvajan R.,Empirical analysis on the cosmetic buying behavior of young women in South India,2014,International Journal of Applied Engineering Research,V-9,I-22,P-7361-7366

5) Balakrishnan P., Bharthvajan R.,Whistling in the wind,2014,International Journal of Applied Engineering Research,V-9,I-22,P-7586-7593

6) Krishnan B., Peter M.,Health hazards of Indian Bpo employee-an alarming issue,2014,International Journal of Applied Engineering Research,V-9,I-22,P-7336-7341

7) Kerinab Beenu G.H., Peter M.,Role of insurance in economic development,2014,International Journal of Applied Engineering Research,V-9,I-22,P-7532-7539

8) Balakrishnan P., Peter M., Priyadarsini P.,Efficiency of safety measures for wellbeing of employees in manufacturing industry,2014,International Journal of Applied Engineering Research,V-9,I-22,P-7376-7382

9) Anbarasi M., Praveen Kumar S.,Online sales promotions of herbal products and its effectiveness towards tanisha.com,2019,Indian Journal of Public Health Research and Development,V-10,I-1,P-195-200

10) Anbarasi M., Praveen Kumar S., Various online marketing and promotions strategies to improve the validation towards the organic products in the pharmaceutical sectors,2019,Indian Journal of Public Health Research and Development, V-10,I-1,P-263-269

11) Loganathan R., Praveen Kumar S.,Grievance handling a key factor for solving issues of employees in an organization,2014,International Journal of Applied Engineering Research,V-9,I-22,P-7483-7491

12) Loganathan R., Praveen Kumar S.,Study on preference of private label brands in super and Hypermarkets,2014,International Journal of Applied Engineering Research,V-9,I-22,P-7327-7335

13) Smitha M., Praveen Kumar S.,Understanding stress and its managementamong the nurses in Chennai city,2014,International Journal of Applied Engineering Research,V-9,I-22,P-7560-7565
14) Kerinab Beenu G.H., Praveen Kumar S.,A study on the investment behavior of Chennai investors in mutual fund schemes,2014,International Journal of Applied Engineering Research,V-9,I-22,P-7520-7525

15) Loganathan R., Praveen Kumar S.,Retention strategies key for organizational productivity,2014,International Journal of Applied Engineering Research,V-9,I-22,P-7443-7447

16) Pavithra J., Ganesan M., Brindha G.,State wise analysis of microfinance sector in India,2016,International Journal of Pharmacy and Technology,V-8,I-4,P-23417-23432

17) Pavithra J., Ganesan M.,A comparative study on microfinance in India and abroad,2016,International Journal of Applied Business and Economic Research,V-14,I-8,P-5471-5476

18) Pavithra J., Ganesan M.,A study on awareness and impact of micro-financial schemes,2016,International Journal of Applied Business and Economic Research,V-14,I-8,P-5449-5460

19) Senthilmurugan P., Pavithra J.,Consumer preference towards organised retailing with reference to Big Bazaar,2014,International Journal of Applied Engineering Research,V-9,I-22,P-7469-7475

20) Senthilmurugan P., Pavithra J.,Implication of social media marketing in growing healthcare industry,2014,International Journal of Applied Engineering Research,V-9,I-22,P-7448-7456

21) Loganathan R., Pavithra J.,Consumer perception towards private label brand over other brands in super markets and hypermarkets,2014,International Journal of Applied Engineering Research,V-9,I-22,P-7355-7360

22) Kerinab Beenu G., Pavithra J.,Tradeâ€"off between liquidity and profitability in logistics industry,2014,International Journal of Applied Engineering Research,V-9,I-22,P-7398-7401

23) Kerinab Beenu G., Pavithra J.,A study on the prospective consumerâ $€^{\mathrm{TM}_{\mathrm{S}}}$ perception towards utility cars in Chennai city,2014,International Journal of Applied Engineering Research,V-9,I-22,P-7526-7531

24) Pavithra J., Dilli Babu P., Ambuli T.V.,A study on budgetary control at Maruti Service Masters, Chennai,2014,International Journal of Applied Business and Economic Research,V-12,I-2,P-151-161

25) Pavithra J., Dilli Babu P., Ambuli T.V.,A study on customer satisfaction of retro Garments Pvt Ltd, Chennai,2014,International Journal of Applied Business and Economic Research,V-12,I-2,P-381-391

26) Kerinab Beenu G.H., Pavithra J., Senthilmurugan P.,A study on the influence of promotional activities for TATA ARIA among consumers in Chennai,2014,International Journal of Applied Engineering Research,V-9,I-22,P-7572-7578

27) Vijayaragavan S.P.,An investigative expert that's general FBG sensors,International Journal of Mechanical Engineering and Technology,V-8,I-8,PP-1500-1505,Y-2017

28) Vijayaragavan S.P.,Equalization routing protocol for Wi-Fi sensor strategy,International Journal of Mechanical Engineering and Technology,V-8,I-8,PP-1662-1666,Y-2017

29) Karthik B., Kiran Kumar T.V.U., Vijayaragavan P., Bharath Kumaran E.,Design of a digital PLL using 0.35 $\hat{\mathrm{I}}^{1}$ /4m CMOS technology,Middle East Journal of Scientific Research,V-18,I-12,PP-1803-1806,Y-2013

30) Kanniga E., Selvaramarathnam K., Sundararajan M.,Kandigital bike operating system,Middle - East Journal of Scientific Research,V

31) Jasmin M., Vigneshwaran T., Beulah Hemalatha S.,Design of power aware on chip embedded memory based FSM encoding in FPGA,International Journal of Applied Engineering Research,V-10,I-2,PP-4487-4496,Y-2015

32) Jasmin M.,Optimization techniques for low power VLSI circuits,Middle East Journal of Scientific Research,V-20,I-9,PP-1082-1087,Y-2014

33) Jasmin M., Vigneswaran T.,Fuzzy controller for error control of on - Chip communication,2017 International Conference on Algorithms, Methodology, Models and Applications in Emerging Technologies, ICAMMAET 2017,V-2017-January,I-,PP-1-5,Y-2017 


\section{AUTHORS PROFILE}

K.Premalatha, StudentDepartment of MBA,Bharath institute of Higher Education \& Research,Tamilnadu,India,

Mr. Gowtham Aashirvad, Assistant Professor, Department of MBA,Bharath institute of Higher Education \& Research,Tamilnadu,India

Dr.A.Kamal Associate Professor, Department of EEE,Bharath institute of Higher Education \& Research, Tamilnadu, India, Email: ak2_anvi@yahoo.co.in 